\title{
Static analysis of the stresses of clutch components with infinitely variable adjustment of the torsional flexibility using FEM
}

\author{
Analiza statyczna naprężeń elementów sprzęgła \\ z bezstopniową regulacją podatności skrętnej \\ z wykorzystaniem MES
}

\section{PAWEK KOŁODZIEJ MAREK BORYGA *}

DOI: https://doi.org/10.17814/mechanik.2017.11.178
Principles, characterization and stress analysis of the clutch components with infinitely variable adjustment of the torsional flexibility at the load occurring during the operation of the machine drive system, are presented. The finite element method was used for the stress analysis of the clutch. Results of the analysis confirm the correctness of the clutch construction in terms of their strength.

KEYWORDS: flexibility clutch, variable torsional stiffness, stress analysis, finite element method

Selection of characteristics of the couplings susceptible to changing operational conditions has a significant impact on mechanical loads, which, after exceeding the limit values, negatively affect the durability, reliability and accuracy of drive systems of machines and devices. Dynamic loads can be reduced in the drive system, for example by using a clutch which, due to its design, can achieve a variable torsional rigidity.

In publications [1, 2], the construction and theoretical and experimental analysis of the flexible coupler are presented, where compression springs are applied. The clutch transmits torque of considerable value and limits the effect of instantaneous overloads, and the change of rigidity is achieved by means of a threaded mechanism. Numerical simulation allowed to evaluate the safety of construction on the basis of determined stress values.

The author [3] proposed adding the insertion clutch into the adjusting nut. It allows the change of pressure of the elastic elements and infinitely adjustable characteristics of the insert to the operating conditions.

In the work [6], a new design of the spring clutch was proposed. The analytical method and the finite element method (FEM) were used for calculating the angle of the spiral spring. The reliability of the results obtained is consistent with numerical and analytical calculations.

\footnotetext{
* Paweł Kołodziej PhD Eng. (pawel.kolodziej@up.lublin.pl), Marek Boryga PhD Eng. (marek.boryga@up.lublin.pl) - University of Life Sciences in Lublin
}

The purpose of this work was to determine the stresses in the coupling components with varying torsional susceptibility [5]. Geometric, material and dynamic features (load moment and clutch susceptibility) were taken into account. Inventor Professional 2017 software has been used to enable $3 D$ modeling of coupling components, assembling them into assemblies, and then determining the distribution of stresses and deformations.

Description and characteristics of the variable torsional susceptibility coupling

Fig. 1 shows the 3D model of the coupling with the ability to control the steering. In the input shaft 1 , there is a stepper motor 2, which drives the gear 3 of the lead screw 4. The screw having the ability to rotate in the active disc 5 and the resistant disc 6 serves to move the control disc 7 , in which the bearing rolls 14 are rotated. The axial displacement of the control disc along the splined shaft 8 , changes the active length of the flat springs 9, decreasing the twisting angle between the active disc 5 and the passive disc 10, to which the output shaft 11 is connected. The flat springs are rigidly attached by means of pins 13 in the holders 12, which can freely rotate in discs 5 and 10 .

To determine the plot of the torsional rigidity coefficient of the coupling $k$, depending on the linear displacement of the control disc $x$ and the consequent changes in the active length $L$ of the parallel spring system, the relation [4] is used:

$$
k=\frac{3 \cdot n \cdot d^{2} \cdot E \cdot J_{x}}{4000 \cdot L^{3}}
$$

where: $n$ - number of springs, $d$-spring diameter in $\mathrm{mm}$, $J_{x}-$ moment of inertia of spring section in $\mathrm{mm}^{4}, E-$ modulus of elasticity in $\mathrm{MPa}, L-$ active spring length in $\mathrm{mm}$. 


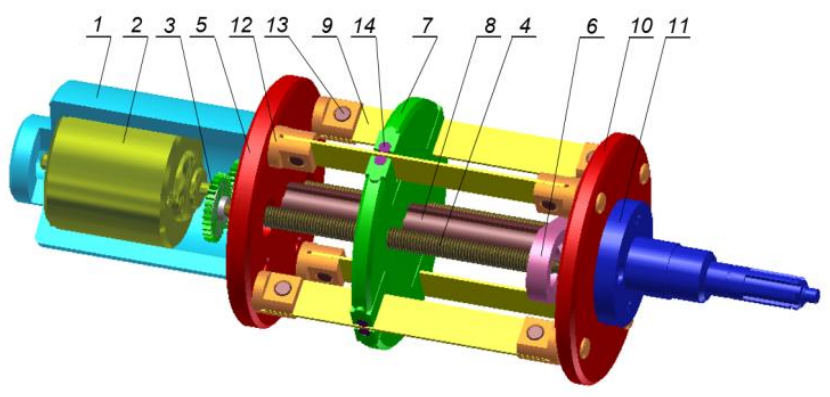

Fig. 1. The design of the coupling with adjustable torsional control

After substitution:

$$
\frac{3 \cdot n \cdot d^{2} \cdot E \cdot J_{x}}{4000}=A
$$

and:

$$
L=L_{c}-x
$$

a simplified form is:

$$
k=\frac{A}{\left(L_{c}-x\right)^{3}}
$$

where: $A$ - coupling constant, $L_{C}-$ total length of springs.

The torsional rigidity coefficient diagram shown in fig. 2 was obtained for: $n=4, d=100 \mathrm{~mm}, J_{x}=5.625$ $\mathrm{mm}^{4}, E=2 \times 10^{5} \mathrm{MPa}, L_{C}=100 \mathrm{~mm}, x=(5 \div 95) \mathrm{mm}$. For these values, the calculated coupling constant was $A=$ $33750000 \mathrm{~N} \cdot \mathrm{m} \cdot \mathrm{mm}^{3} \cdot \mathrm{rad}^{-1}$.

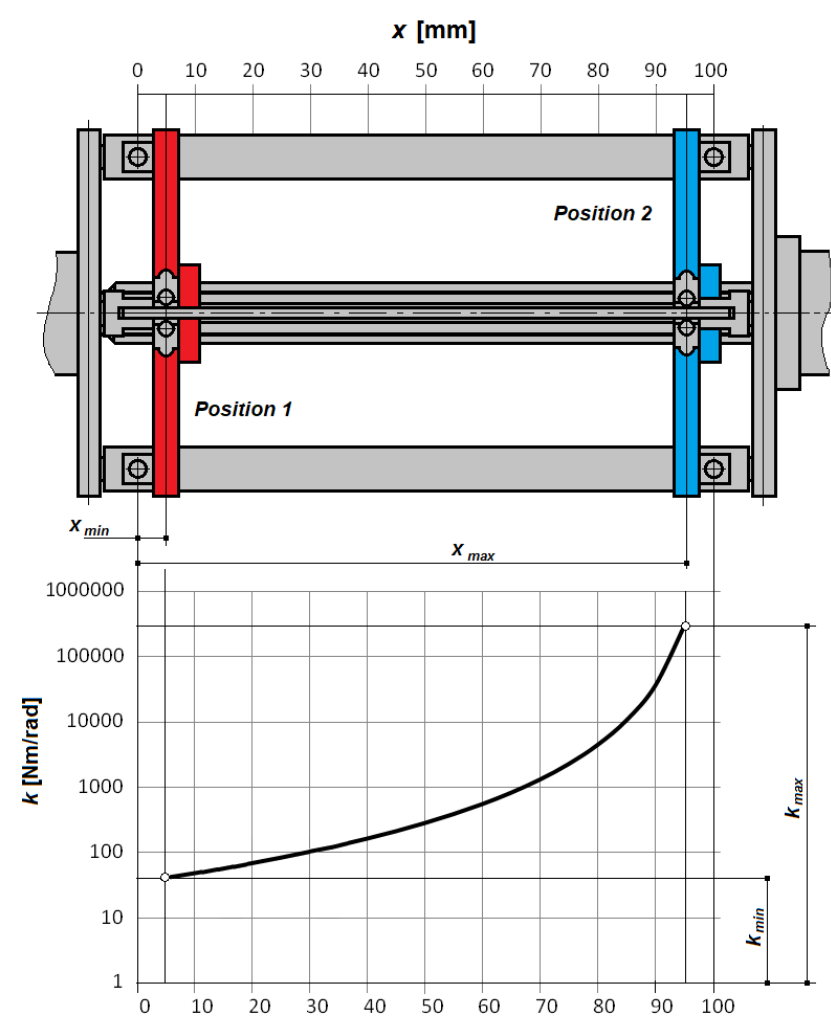

Fig. 2. Dependence of the torsional rigidity coefficient of the coupling on the linear displacement of the control disc

\section{Results of numerical analysis}

Torque transmission components were included, and the operation of the changeover control units (stepper motor, gear, pulling screw) was omitted. The input disc was loaded with a torque of $M=5 \mathrm{Nm}$, while the output disc was fixed, and the surface of the dowel holes were used to fix the output shaft for fixing the output shaft. Material defined in the Inventor Professional 2017 database was used. The selection of clutch materials was preceded by a mechanical properties analysis, as shown in the table.

Automatically generated Linked bindings have been manually modified to ensure the correct interaction of the coupling components in the assembly [7]. Incremental accuracy was achieved by changing the standard spatial grid settings. The mesh compaction was based on the information in [7], assuming a Maximum mesh angle of $30^{\circ}$. It was also decided to change in convergence. The Maximum number of smoothing $(h)$ of six and the Stopping criterion of $2 \%$ were assumed. These settings mean that the program performs the calculation several times (up to six times), modifying the grid at every point of occurrence of the maximum stresses until the difference in results in subsequent repetitions does not exceed $2 \%$.

\section{TABLE. Mechanical properties of materials used}

\begin{tabular}{|c|c|c|c|c|l|}
\hline Material & $\begin{array}{c}\text { Poisson } \\
\text { number } \\
v\end{array}$ & $\begin{array}{c}\text { Young's } \\
\text { modulus } \\
E, \mathrm{GPa}\end{array}$ & $\begin{array}{c}\text { Yield } \\
\text { strength } \\
R_{e}, \mathrm{MPa}\end{array}$ & $\begin{array}{c}\text { Strength } \\
\text { limit } R_{m}, \\
\mathrm{MPa}\end{array}$ & Elements \\
\hline $\begin{array}{c}\text { Non- } \\
\text { alloy } \\
\text { steel }\end{array}$ & 0,30 & 210 & 250 & 300 & $\begin{array}{l}\text { Input } \\
\text { disc, } \\
\text { output } \\
\text { disc, } \\
\text { control } \\
\text { disc }\end{array}$ \\
\hline $\begin{array}{c}\text { Carbon } \\
\text { steel }\end{array}$ & 0,29 & 200 & 350 & 420 & $\begin{array}{l}\text { Spring } \\
\text { holder, } \\
\text { spring, } \\
\text { spring } \\
\text { holder pin }\end{array}$ \\
\hline $\begin{array}{c}\text { Alloy } \\
\text { steel }\end{array}$ & 0,30 & 205 & 250 & 400 & $\begin{array}{l}\text { Main } \\
\text { shaft, } \\
\text { control } \\
\text { disc shaft }\end{array}$ \\
\hline
\end{tabular}

Stress analysis was performed for the two extreme positions of the control disc as shown in fig. 2. In the first position of the disc, $x_{\min }=5 \mathrm{~mm}$, length of the springs was $L_{\max }=95 \mathrm{~mm}$, while in the second position, $x_{\max }=95$ $\mathrm{mm}$, length of the springs was $L_{\min }=5 \mathrm{~mm}$.

In the first position, the system generated a grid with the number of elements 206122 and the number of nodes 341110 . In the second position, the number of elements was 1592716 , while number of nodes was 2428 815. Graphical representation of the results of stress analysis based on the Huber-Mises-Hencky hypothesis $(\mathrm{HMH})$ is shown in fig. 3 .

Figs. 4-6 show the reduced stress distribution for three clutch components that exhibited the highest stress values, i.e. spring holder pin, spring, and spring holder.

Column diagram (fig. 7) lists the values of reduced stresses for individual clutch elements, calculated according to the $\mathrm{HMH}$ hypothesis. 
a)

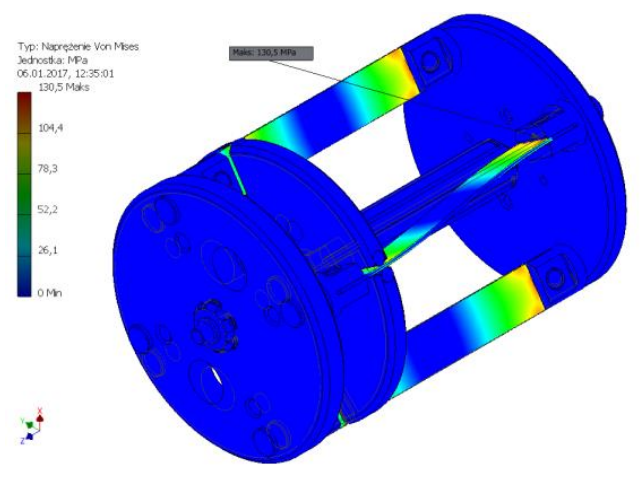

b)

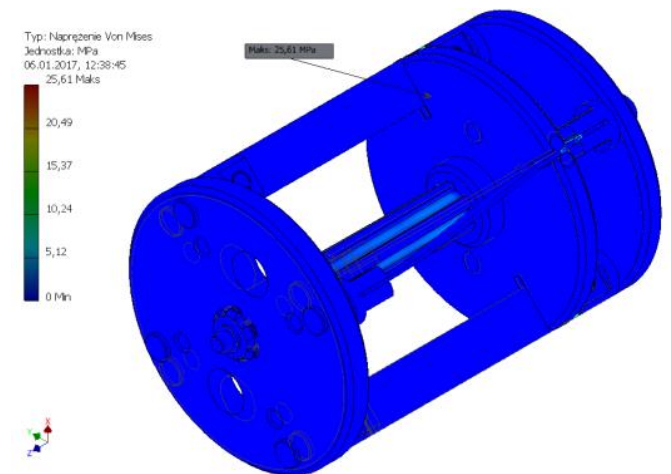

Fig. 3. Reduced stress distribution in the coupling for: a) $x_{\min }, b$ ) $x_{\max }$

a)

\section{Typ: Naprężenie Von Mises}

Jednostka: $\mathrm{MPa}$

$05.01 .2017,10: 10: 15$

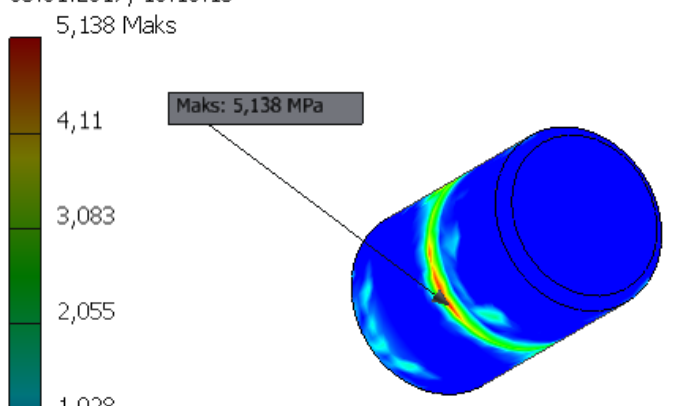

1,028

0,031 Min

b)

Typ: Naprężenie Von Mises

Jednostka: $\mathrm{MPa}$

$04.01 .2017,19: 46: 01$

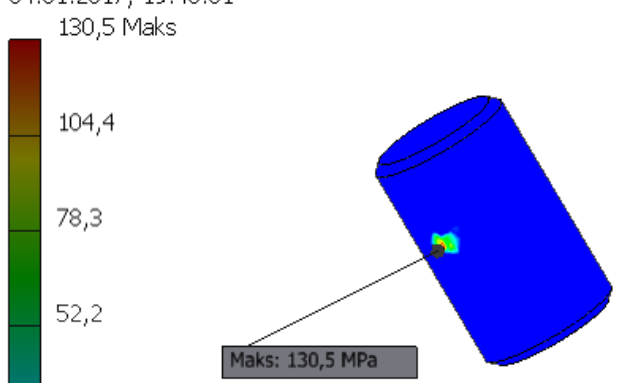

26,1

0 Min

Fig. 4. Reduced stress distribution (in $\mathrm{MPa}$ ) in the spring holder pin for: a) $x_{\min }$, b) $x_{\max }$ a)

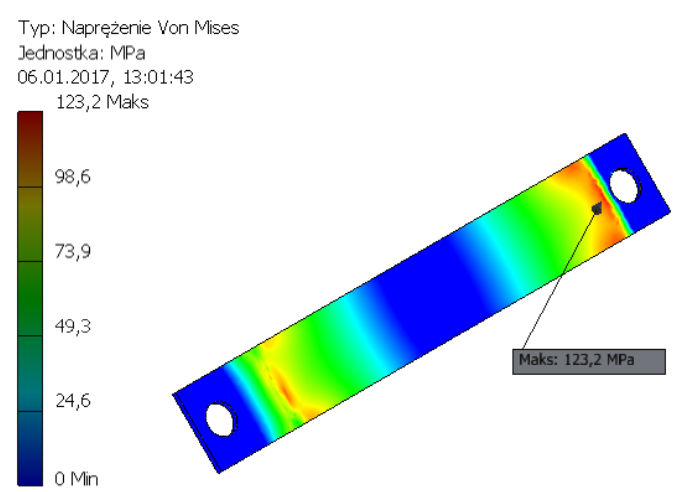

b)

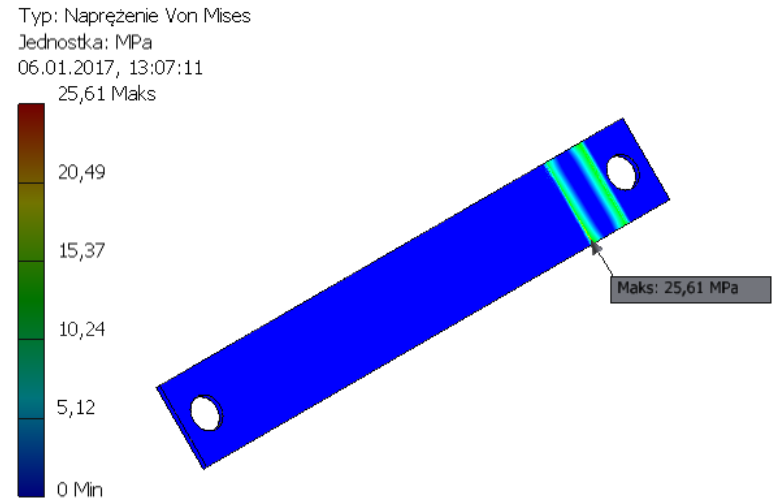

Fig. 5. Reduced stress distribution (in $\mathrm{MPa}$ ) in spring for: a) $x_{\text {min }}$, b) $x_{\max }$

a)

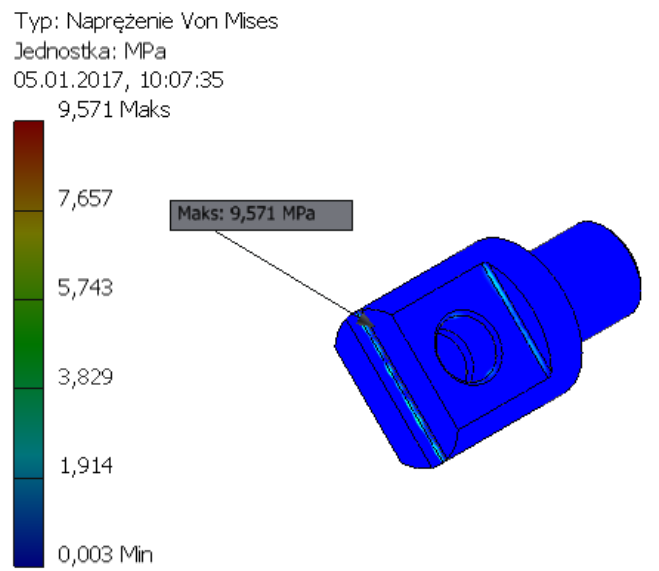

b)

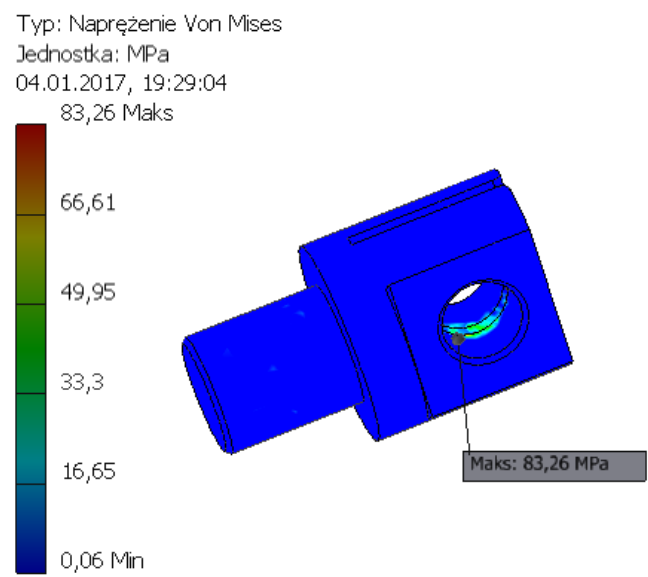

Fig. 6. Reduced stress distribution (in MPa) in the spring holder for: a) $\left.x_{\min }, b\right) x_{\max }$ 


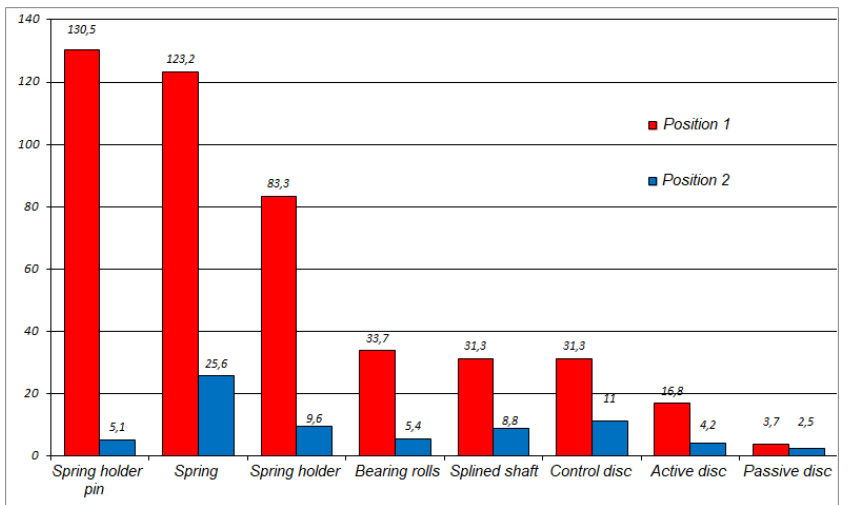

Fig. 7. Stress values for individual components of the clutch depending on the position of the control disc

\section{Conclusions}

The FEM analysis of coupling has allowed to assess its strain at nonlinear changes in rigidity and load occurring during the drive system.

It can be stated that:

- Higher values of reduced stresses in the individual coupling components were observed in first position, where the length of springs was the largest. The reduced stresses of the elements in second position did not exceed $36 \%$ of the stress values at first position. The exception is the output disk, in which the stresses were reduced to the smallest value.

- The highest values of reduced stresses were observed in the spring - 123.2 $\mathrm{MPa}$ and in the elements cooperating with the spring, i.e. the holder pin - 130.5 $\mathrm{MPa}$ and the spring holder - 83.3 Mpa.

- In the case of spring, spring holder and output disc, the maximum reduced stresses changed their positions.

- The minimum value of the safety factor, relative to the yield strength of 2.68 , confirms the correctness of the coupling structure in terms of its strength.

\section{REFERENCES}

1. Filipowicz K. „Determining of the static characteristics of a torsionally flexible metal coupling". Acta Montanistica Slovaca. 12, 4 (2007): pp. 304-308.

2. Filipowicz K., Kuczaj M. „Komputerowa analiza naprężeń w wybranych elementach metalowego sprzęgła podatnego skrętnie". Przegląd Mechaniczny. 2 (2010): pp. 45-49.

3. Gruszka P. „Zalety sprzęgła podatnego ze zmienną charakterystyką w napędzie". Zeszyty Naukowe Politechniki Śląskiej. Seria: Transport. 53 (2004): pp. 43-50.

4. Kołodziej P., Boryga M. „Frequency analysis of coupling with adjustable torsional flexibility". Eksploatacja $i$ Niezawodność - Maintenance and Reliability. 16, 2 (2014): pp. 325-329.

5. Kołodziej P., Stępniewski A. Sprzęgło podatne. Patent PL 193910 B1.

6. Mambetow A.D., Bajramukow A.O., Kruczek W. „Projektowanie sprzęgła kompensacyjnego”. Mechanik. 10 (2015): pp. 812-816.

7. Stasiak F. „Zbiór ćwiczeń Autodesk ${ }^{\circledR}$ Inventor $^{\circledR}$ 2015. Kurs Professional". ExpertBooks. 2015. 